\title{
DOES METFORMIN PLAY A ROLE IN THE TREATMENT OF ACNE?
}

\section{Ana Maria A. STANESCU1, loana V. GRAJDEANU1, Daniela MIRICESCU², Bogdan SERBAN1,2, Horia LAZARESCU ${ }^{4}$, Florin BREZAN ${ }^{1,5}$, Andrei KOZMA ${ }^{4,5}$}

${ }^{1}$ University of Medicine and Pharmacy „Carol Davila“, Bucharest, Romania

2 Discipline of Biochemistry, Faculty of Dental Medicine, „Carol Davila“ University of Medicine and Pharmacy Bucharest, Romania

${ }^{3}$ Emergency University Hospital Bucharest, Bucharest, Romania

${ }^{4}$ National Institute for Recovery, Physical Medicine and Balneoclimatology, Bucharest, Romania

5 „Alessandrescu - Rusescu“ National Institute for Mother and Child Health, Bucharest, Romania

*All authors had an equal contribution to the article

Received 03 Oct 2019, Accepted 10 Nov 2019

https://doi.org/10.31688/ABMU.2019.54.4.20

\begin{abstract}
Although a common condition, acne is a complex condition that involves chronic inflammation and hyperkeratosis of the hair follicles, increased sebum secretion, and colonization of Propionibacterium acnes. Metformin has been found to play a role in acne, particularly hormonal acne. Our goal is to review the relevant studies and their results following metformin administration in patients with acne.
\end{abstract}

Keywords: acne, metformin, insulin.

\section{INTRODUCTION}

Acne is a disease of the pilosebaceous unit that has the highest frequency in adolescence, however it can persist even into adulthood. Acne affects 33\% of the population between the ages of 15 and $44^{1}$. In

\section{Résumé}

La metformine, joue-telle un rôle dans le traitement de l'acné?

Bien qu'elle soit courante, l'acné est une maladie complexe qui implique une inflammation chronique et une hyperkératose des follicules pileux, une sécrétion accrue de sébum et la colonisation de Propionibacterium acnes. La metformine joue un rôle dans l'acné, en particulier l'acné hormonale. Notre objectif est de passer en revue les études pertinentes et leurs résultats après l'administration de metformine.

Mots-clés: acné, metformine, insuline.

the United States, approximately 50 million people suffer from acne, which can be considered a common condition ${ }^{2}$.

Although a common condition, acne is a complex disease that involves chronic inflammation and hyperkeratosis of the hair follicles, increased sebum 


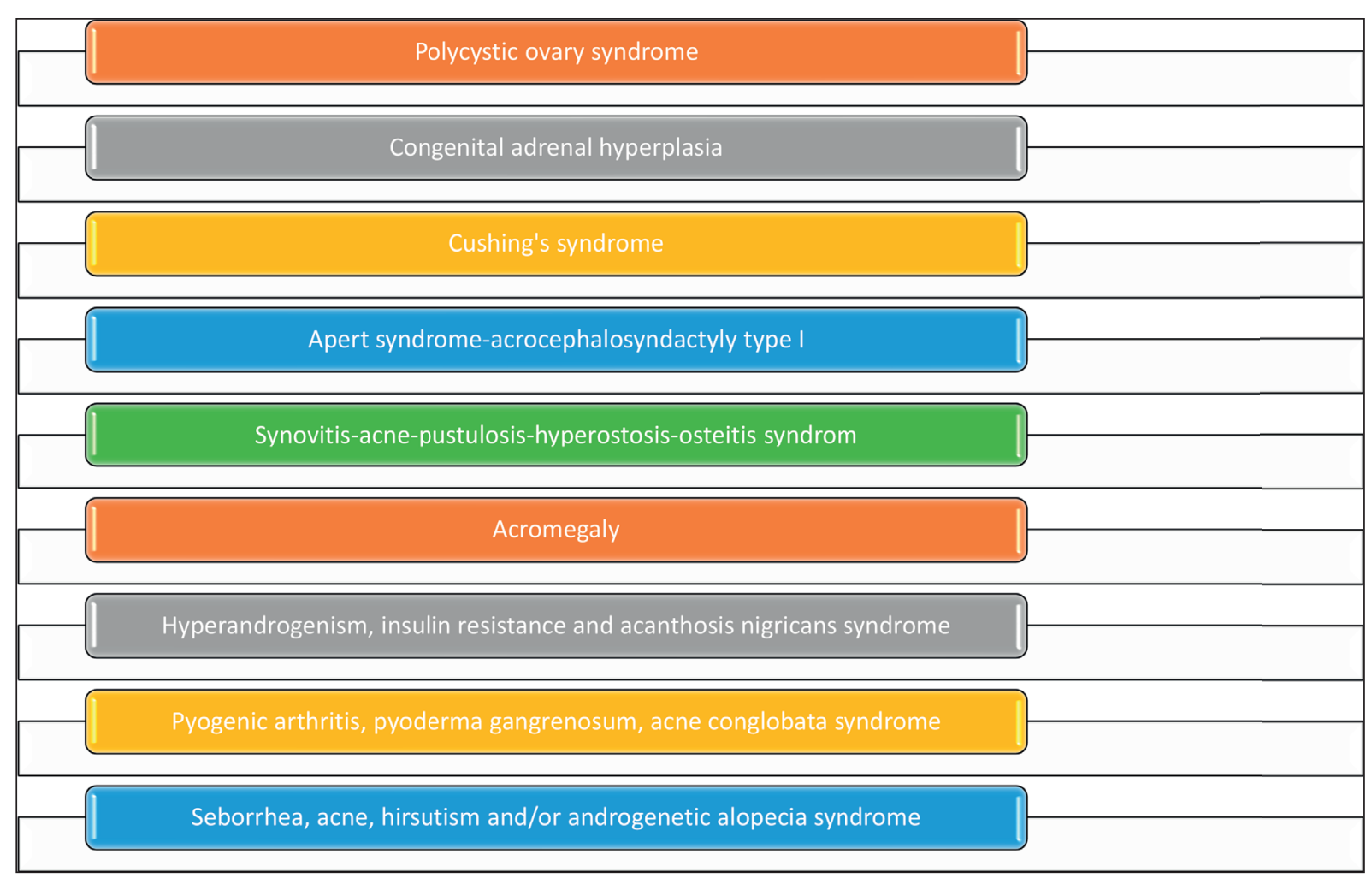

Figure 1. Syndromes associated with hormonal imbalances in acne $e^{6-8}$.

secretion and colonization of Propionibacterium acnes ${ }^{3,4}$. The sebum secretion begins to increase with the onset of puberty, being in accordance with the maximum levels of growth hormone and insulin-like growth factor (IGF-1)

A direct correlation was observed between serum IGF-1 levels and the average rate of facial sebum excretion in post-adolescent individuals with acne, and serum levels of dehydro-testosterone and dehydro-epiandrosteronate sulfate correlated with serum levels of IGF-19.

\section{Aspects of INSULIN IN ACNE}

Insulin is structurally similar to the IGF-1 receptor and binds to it. In very high doses, insulin regulates $\mathrm{GH}$ receptor expression on sebocytes. Also, insulin stimulates the production of ovarian and adrenal androgens, inhibits the production of sex hormone binding globulin (SHBG) in the liver, can act as a key regulator of lipid biosynthetic enzymes by stimulating the production of ovarian and adrenal androgens and inhibiting the production of SHBG ${ }^{11-13}$.

Although the role of diet in acne is controversial, it has been proposed that with high glycemic load, plasma insulin concentrations, which regulate androgen levels, IGF-1 and IGF-binding proteins, promote irregular tissue growth and improve androgen synthesis ${ }^{14}$. Recent studies have shown that Western diets increase the prevalence of acne through three major compounds identified in acne pathogenesis, namely: hyperglycemic carbohydrates, milk and dairy products and saturated fat ${ }^{15}$. A new perspective is emerging on nutrient signaling in vulgar acne, both through high glycemic load and increased insulin, IGF-1 and leucine signaling due to dairy protein intake ${ }^{15,16}$.

Smith et al compared the effects of a diet with a low glycemic index versus a high glycemic index on acne. The low glycemic group had a significant decrease in the number of acne lesions, the free androgen index, and a significant increase in insulin sensitivity and IGFBP-1 compared with the high glycemic diet group ${ }^{17}$.

Serum IGF-1 levels increase in polycystic ovary syndrome and acromegaly ${ }^{18}$. Recombinant human IGF-1 leads to androgenesis and acne ${ }^{19}$. Diets with a high glycemic index are associated with hyperglycemia, reactive hyperinsulinemia and increased levels of IGF-120,21. Cow's milk contains active IGF-1 and IGF-2, which are not destroyed by pasteurization and due to the structural similarity between bovine IGF-1 and human IGF-1, both bind to human IGF-1R ${ }^{22}$.

\section{THE EFFECT OF METFORMIN IN ACNE}

Metformin has been found to play a role in acne, especially hormonal acne $e^{23}$. 
Tan et al conducted a study in Germany, on 188 women suffering from polycystic ovary syndrome. Underweight, overweight and obese patients received metformin at a dose between 500 and $1000 \mathrm{mg}$ twice daily for 6 months; in this study, it was observed the reduction of acne severity, menstrual cycle regulation, regulation of insulin resistance and regulation of testosterone levels ${ }^{24}$.

Ibáñez et al demonstrated in patients with androgen excess and hyperinsulinemia that a low dose combination of metformin, pioglitazone and flutamide not only helped reduce acne, but also had beneficial effects in biochemical parameters such as hyperinsulinemia, hypercholesterolemia and hypertriglyceridemia ${ }^{25}$.

Fabbrocini et al evaluated metformin as an adjunctive treatment to a hypoglycemic diet in patients with altered metabolic profile, including men aged 17 to 24 years, with acne for at least 1 year, which was resistant to common therapies. He used two groups, one with metformin $500 \mathrm{mg}$ and adjuvant therapy for acne and one only with adjuvant therapy for acne. The metformin group did not report any adverse effects and there was a significant improvement in acne and a statistically significant positive correlation for the HOMA-IR level with the metformin group ${ }^{26}$.

Gabaton et al evaluated metformin as an adjuvant treatment to lymecycline and adapalene + benzoyl peroxide in patients with moderate to severe common acne. The mean speed of reduction in the total number of inflammatory lesions was higher in the metformin group than in the placebo group ( $\mathrm{p}$ $<0.05$ ). Systemic adverse events were self-limiting and included flatulence, headache, diarrhea and epigastric pain ${ }^{27}$.

Robinson and Affandi evaluated metformin as an adjuvant treatment to topical benzoyl peroxide and oral tetracycline. One group received $850 \mathrm{mg}$ of metformin daily with $2.5 \%$ topical benzoyl peroxide and oral tetracycline twice daily, the second group received only $2.5 \%$ topical benzoyl peroxide and oral tetracycline twice daily. The rate of acne improvement was significantly higher in the metformin group at $66.7 \%$ compared to the control group at $43.2 \%$ (p $=0.04$ ). Gastrointestinal symptoms were reported in $31.7 \%$ of the metformin group ${ }^{28}$.

De Leo et al studied the effects of metformin administration on ovulatory function, acne, hirsutism, hormonal patterns and body weight in adolescent girls with polycystic ovary syndrome. The study enrolled 80 girls (aged 15-18 years), who received 1,700 $\mathrm{mg}$ of metformin daily for six months. Acne showed an improvement in severity after six months of treatment, occurred an improvement in the regularity of the menstrual cycle, with a significant reduction in testosterone, androstenedione and free testosterone level, and body mass index was normalized ${ }^{29}$.

Israni et al studied the effects of metformin on vulgar acne and other conditions of hyperandrogenism associated with polycystic ovary syndrome in 17 women who were given metformin for three months. At the end of the three months of treatment, a significant decrease (71\%) of the acne severity scores was observed $^{30}$.

Girls with early puberty and low birth weight may have elevated serum IGF-1 and insulin resistance, leading to rapid puberty progression and a predisposition to developing polycystic ovary syndrome. In this category of patients, metformin treatment prevented the onset of early puberty by 0.4 years and significantly decreased serum levels of IGF-1, post insulin, DHEAS and testosterone ${ }^{31,32}$.

Insulin resistance is characterized by decreased cellular uptake of glucose and normal or increased serum levels of insulin ${ }^{33,34}$. Within the insulin resistance, the intracellular insulin-sensitive glucose transporter 4 (GLUT4) is significantly reduced. Hyperinsulinemia and hyperglycemia result in increased GLUT4 cell endocytosis, which results in decreased glucose uptake. GLUT4 endocytosis is reversed by metformin treatment ${ }^{35}$.

Regarding the adverse effects of metformin administration, a longitudinal, interventional study of 40 patients observed reversible gastrointestinal adverse reactions in approximately $20 \%$ of the participants. Adverse reactions consisted of diarrhea, nausea, abdominal discomfort, anorexia and a metallic taste in the mouth. Adverse reactions were not severe and were altered by the administration of metformin with food, as well as by the administration of $\mathrm{H} 2$ blockers for the first 1 to 2 weeks of metformin therapy. Only 2 women in the 40 patients had severe gastrointestinal side effects, with discontinuation of metformin treatment necessary ${ }^{36}$.

\section{Conclusions}

Metformin can be an effective and safe adjuvant treatment in the treatment of moderate to severe vulgar acne. Few studies have focused on the effects of metformin on vulgar acne. We believe that more randomized and controlled trials are needed to confirm the efficacy of metformin in acne.

\section{Compliance with Ethics Requirements:}

"The authors declare no conflict of interest regarding this article" 


\section{References}

1. Stern RS. The prevalence of acne on the basis of physical examination. J Am Acad Dermatol 1992;26:931-935.

2. Zaenglein AL, Pathy AL, Schlosser BJ, et al. Guidelines of care for the management of acne vulgaris. J Am Acad Dermatol. 2016;74(5):945-973.e33.

3. Gollnick HP. From new findings in acne pathogenesis to new approaches in treatment. J Eur Acad Dermatol Venereol. 2015;29(Suppl 5):1-7.

4. Stanescu AMA, Matei A, Grajdeanu IV, et al. Acneea fulminans - urgenta medicala in practica medicului de familie. Practica Medicala 2017;12,4(53):224-227.

5. Emiroğlu N, Cengiz FP, Kemeriz F. Insulin resistance in severe acne vulgaris. Postepy Dermatol Alergol. 2015;32(4):281-285.

6. Rus-Hrincu F, Totan A, Stanescu AMA, et al. DUOX2, a new player on the scene of thyroid hormones. Practica Medicala 2019;14,3(67):270-272.

7. Gheorghe G, Ilie M, Socea B, et al. Budd-Chiari syndrome. Arch Balk Med Union 2019;54(2):345-350.

8. Anghel R, Iorga L, Marcu D, et al. The role of Bosniak classification in the assessment of renal cystic masses and in the therapeutical protocol. Arch Balk Med Union 2018;53(3):445-448

9. Vora S, Ovhal A, Jerajani H, et al. Correlation of facial sebum to serum insulin-like growth factor-1 in patients with acne. Br J Dermatol. 2008;159:990-1.

10. Deplewski D, Rosenfield RL. Role of hormones in pilosebaceous unit development. Endocr Rev 2000;21:363-92.

11. Miricescu D, Totan A, Stanescu AMA, et al. Deficienta de vitamina D si rezistenta la insulina. Practica Medicală 2019;14,3(67):227-232.

12. Smith TM, Gilliland K, Clawson GA, Thiboutot D. IGF-1 induces SREBP-1 expression and lipogenesis in SEB-1 sebocytes via activation of the phosphoinositide 3-kinase/Akt pathway. J Invest Dermatol 2008;128:1286-93

13. Bratu OG, Marcu RD, Socea B, et al. Immunohistochemistry particularities of retroperitoneal tumors. Rev Chim (Bucharest). 2018;69(7):1813-1816.

14. Marcu RD, Spinu AD, Socea B, et al. Castleman's disease clinical, histological and therapeutic features. Rev Chim (Bucharest). 2018;69(4): 823-830.

15. Melnik BC. Linking diet to acne metabolomics, inflammation, and comedogenesis: an update. Clin Cosmet Investig Dermatol, 2015;8:371-388

16. Melnik BC. Dietary intervention in acne: attenuation of increased mTORC1 signaling promoted by Western diet. Dermatoendocrinol, 2012;4:20-32

17. Smith RN, Mann NJ, Braue A, et al. The effect of a high-protein, low glycemic-load diet versus a conventional, high glycemic-load diet on biochemical parameters associated with acne vulgaris: a randomized, investigator-masked, controlled trial. J Am Acad Dermatol, 2007;57: 247-256.

18. Thierry van Dessel HJ, Lee PD, Faessen G, et al. Elevated serum levels of free insulin-like growth factor I in polycystic ovary syndrome. J Clin Endocrinol Metab 1999;84:3030-5.

19. Rosenbloom AL. The role of recombinant insulin-like growth factor I in the treatment of the short child. Curr Opin Pediatr 2007;19:458-64.
20. Smith RN, Mann NJ, Braue A, et al. The effect of a high-protein, low glycemic-load diet versus a conventional, high glycemic-load diet on biochemical parameters associated with acne vulgaris: A randomized, investigator-masked, controlled trial. J Am Acad Dermatol 2007;57:247-56.

21. Stanescu AMA, Grajdeanu IV, Stefani C, et al. Eficacitatea si efectele adverse ale terapiilor complementare si alternative în acnee. Practica Medicala 2019;14,1(64):34-39.

22. Blum JW, Baumrucker CR. Insulin-like growth factors (IGFs), IGF binding proteins, and other endocrine factors in milk: role in the newborn. In: Bosze Z, editor. Biactive Components of Milk. Advances in Experimental Medicine and Biology. vol. 606. New York: Springer; 2008. p. 397-422.

23. Karnilli E, Armoni M. Transcriptional regulation of the insulin responsive glucose transporter GLUT 4 gene: From physiology to pathology. Am J Physiol Endocrinol Metabol. 2008;295:E38-45.

24. Tan S, Hahn S, Benson S, et al. Metformin improves polycystic ovary syndrome symptoms irrespective of pre-treatment insulin resistance. Eur J Endocrinol. 2007;157:669-76.

25. Ibáñez L, Diaz M, Sebastiani G, et al. Treatment of androgen excess in adolescent girls: Ethinylestradiol-cyproteroneacetate versus low-dose pioglitazone-flutamide- metformin. J Clin Endocrinol Metab. 2011;96:3361-6.

26. Fabbrocini G, Izzo R, Faggiano A, et al. Low glycaemic diet and metformin therapy: a new approach in male subjects with acne resistant to common treatments. Clin Exp Dermatol. 2016;41(1):38-42.

27. Lee JK, Smith AD. Metformin as an adjunct therapy for the treatment of moderate to severe acne vulgaris. Dermatology Online Journal 2017;23(11):5.

28. Robinson S, Kwan Z, Tang MM. Metformin as an adjunct therapy for the treatment of moderate to severe acne vulgaris: A randomized open-labeled study. Dermatologic Therapy. 2019; 32:e12953.

29. De Leo V, Musacchio MC, Morgante G, et al. Metformin treatment is effective in obese teenage girls with PCOS. Hum Reprod. 2006;21(9):2252-2256.

30. Israni DA, Mehta TY, Shah SR, Goyal RK. Effect of metformin therapy in female visiting dermatologist for acne vulgaris having endocrine and sonographic characteristics of polycystic ovary syndrome (PCOS). Asian J Phorm Clin Res. 2013;6(2):1.

31. Ibánez L, Ong K, Valls C, et al. Metformin treatment to prevent early puberty in girls with precocious pubarche. $J$ Clin Endocrinol Metab 2006;91:2888-2891.

32. Diaconu C, Balaceanu A, Bartos D. Diuretics, first-line antihypertensive agents: are they always safe in the elderly? Romanian Journal of Internal Medicine 2014;52(2):87-90

33. Draghici T, Negreanu L, Bratu OG, et al. Liver abnormalities in patients with heart failure. Arch Balk Med Union. 2018;53(1):76-81.

34. Diaconu C, Balaceanu A, Morosan E. Sepsis biomarkers: past, present and future. Farmacia. 2015;63(6):811-815.

35. Pryor PR, Liu SC, Clark AE, et al. Chronic insulin effects on insulin signalling and GLUT4 endocytosis are reversed by metformin. Biochem J 2000;348:83-91.

36. Sharma S, Mathur DK, Paliwal V, Bhargava P. Efficacy of metformin in the treatment of acne in women with polycystic ovarian syndrome: a newer approach to acne therapy. $J$ Clin Aesthet Dermatol. 2019;12(5):34-38. 